\title{
MANDALA E LEMBRANÇAS
}

\author{
Paula Tura é mestranda em Educação, Arte e História da Cultura na Universidade Mackenzie SP. \\ E-mail: paulatura@hotmail.com
}

Faz dezesseis meses que você partiu. Prometi que um dia escreveria nossa história. Ainda não o fiz. Guardo em casa as mandalas que pintei e as que esculpi em barro lembranças de um tempo partilhado com você. Tempo que passou.

Esta noite você visitou meus sonhos: escreva sobre o tempo, você pedia. Penso no tempo e na sua velocidade. Durou três meses o nosso último encontro. Dias longos, calmos, quietos e profundos. Absolutamente convidativos à reflexão.

Ah! Tivemos também momentos descontraídos, "vai!", diria você. É verdade, riamos quando você me contava todas as mentiras que já havia dito. Uma pior que a outra. Lembrome agora daquela sobre o piano mal assombrado que você contava para suas irmãs só para que elas não o tocassem. Pobres crianças que acreditavam existir pequenos monstros de cabeça verde e sanguinolenta morando dentro do piano de caldas. Você foi terrível!

Em outros momentos choramos. De mãos dadas ficávamos por horas até a angústia passar. Às vezes demorava muito, mas logo o dia clareava e tomávamos um novo fôlego.

Sinto saudades do seu cheiro.

Nosso quarto tinha o pé direito alto, com as paredes claras e uma janela grande de onde era possível ver muitas árvores, lembra? Os pássaros cantavam para nós ao entardecer. Eu desligava todos os aparelhos sonoros para ouvir a melodia. A princípio você se incomodava, estranhava a quietude.

Às vezes recebíamos visitas muito a contragosto, pois queríamos ficar a sós. Quando não tinha jeito abríamos a porta e deixávamos o mundo adentrar com sua característica invasiva. Traziam notícias de parentes, quitutes, alegrias, dissabores e um bom tempo de conversa que aproveitávamos como se nada pudesse ser mais importante. Ao final da visita limpávamos a casa toda para espantar o mau olhado, a cobiça, os germes, a chatice da inveja. E aí voltávamos a nós.

Lembra daquela visita que chegou bem na hora do jantar? Como esquecer, não é? Era o dia da sua sopa predileta: mandioquinha com cenoura. Até hoje não sabemos o sabor da sopa. Esqueceu? Como você se esqueceu? Eu entrei na sala com a sopeira cheia e tropecei virando toda a bandeja no chão. Fiquei com uma bolha de queimadura na mão direita. Não sabia se mandava a visita pra puta que o pariu ou se limpava a sujeira. Foi olho gordo eu tenho certeza. Você sorriu e veio me acudir. Aproximou-se do meu ouvido e sussurrou: acalme-se, poderia ter sido muito mais grave. 
E realmente, a visita nunca mais apareceu. Também, já havíamos combinado: se aparecesse não abriríamos a porta e ainda colocaríamos sal grosso e alho nos cantos da casa até que a mesma se fosse. Visitas insolentes.

O melhor de tudo era estar junto. Pra comer, pra dormir, pra falar, pra escutar. Junto, sempre junto. Era um presente. Foi o tempo mais difícil e mais importante da minha vida.

Volto no tempo. Não foi seu pedido? Então agora terei que contar. Lembra quando nos conhecemos? Puxa faz tempo! Foi lindo. Lágrimas escorriam de nossos olhos. Nos abraçamos calorosamente. Daquele momento até hoje compartilhamos nossas diferenças para enfim nestes últimos três meses celebrarmos nossos afetos. Eu jamais imaginei que poderíamos experimentar algo tão profundo. Ouso dizer que foi situação mais dolorida pela qual já passei em minha vida, no entanto, a mais valiosa e indescritível de todas.

Certa tarde você me olhou nos olhos e eu entendi que deveria partir. Voltei para casa com todos os meus pertences. Eu e a cidade não mais nos pertencíamos. É como se eu me encontrasse na fissura do osso quebrado - um não lugar - desconforto.

Tenho uma confissão para fazer: visitei você diariamente por dez dias. Rondei a casa, sorri, relembrei nossos abraços, chorei, espiei pelo buraco da fechadura, colei as mandalas que fiz nas paredes e muros externos. Talvez você nunca tenha sabido. Soube? Como soube? Você me viu por ali? Não, não é possível. E não me chamou? Nunca ousou me chamar?

Queria ter podido ficar mais. Não me permitiram. Te sedaram. Não deixaram que eu te levasse pra casa comigo. Para segurar na tua mão até o último suspiro.

Ainda ouço sua voz e seus passos apressados. Os pássaros continuam a cantar ao entardecer.

E espero a cada dia por uma noite de sonhos com você. 